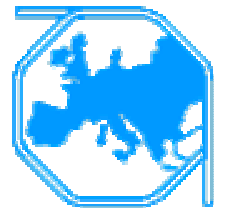

\title{
Urbanization and urban transport in india: the search for a policy
}

\author{
Sudarsanam Padam ${ }^{1 *}$, Sanjay Kumar Singh ${ }^{2}$ \\ ${ }^{1}$ Senior Member of Faculty and Dean of Studies at Administrative Staff College of India, Hyderabad, \\ India \\ ${ }^{2}$ Assistant Professor of Economics in the Department of Humanities and Social Sciences at Indian \\ Institute of Technology, Kanpur, India
}

\begin{abstract}
Urban population in India has increased significantly from 62 million in 1951 to 285 million in 2001 and is estimated to be around 540 million by the year 2021. In terms of percentage of total population, the urban population has gone up from 17\% in 1951 to $29 \%$ in 2001 and is expected to increase up to around $37 \%$ by the year 2021 . Consequently, the number and size of cities have also increased significantly. Although circumstances differ considerably across cities in India, certain basic trends which determine transport demand (such as substantial increase in urban population, household incomes, and industrial and commercial activities) are the same. These changes have placed heavy demands on urban transport systems, demand that many Indian cities have been unable to meet.

This paper attempts to highlight the need for a cogent urban transport policy without which there will be ad hoc interventions. Such interventions, apart from not adding up to a comprehensive approach, will result in greater confusion. Furthermore, it emphasizes that if there is no worthwhile public transport, it will still need to be reinvented to promote a better quality of life. The need of the hour is formulation of an urban transport strategy that is both pragmatic and holistic in its approach.
\end{abstract}

Keywords: Urbanization; Urban Transport Policy.

\section{The present context}

The making of transport policy is a tricky affair. Transport being essentially a derived activity its conceptualization and articulation depends upon a variety of social and economic issues and longer-term goals. India has however attempted twice to evolve a transport policy. The first in 1966 when the dreams of independence were still alive and the second in 1980 under the shadow of zooming oil prices. In a typically oriental fashion, on both the occasions, the policies were accepted in toto by the government and subsequently subjected to studied neglect. The silver lining however was the establishment of State Transport Undertakings (STUs) which in the 1960s and the 1970s did an enormous service in linking up towns and villages across the country, particularly

\footnotetext{
* Corresponding author: Sanjay Kumar Singh (sanjay@iitk.ac.in).
} 
in the western and the southern parts. Even though the service may leave much to be desired in terms of quality, STUs' importance lies in the fact that unlike in most other developing countries one can reach out in India to almost every village.Urban areas in India, which include a wide range of mega cities, cities, towns etc. are not all that lucky in terms of intra-city transportation. Transport in this context has been a victim of ignorance, neglect and confusion - or all these at once. ${ }^{1}$ This is perhaps due to the fact that the majority of urban population was relatively recent migrants and has yet to develop a sense of belonging in order to influence policies. Whatever influence the public had was not so much for improving the quality of transport but in reducing the fares which further added to inadequacy and inefficiency. There is absence of policy in urban areas. Indeed policies are most needed here in view of the complexities in urban infrastructure and the need for greater integration in providing, maintaining and managing urban public utilities. The political and bureaucratic set up has done little to introduce professionalism without which the planning and regulatory measures can only be inadequate, inefficient and at the most half-baked. It is essentially for these reasons that new threats are emerging in the shape of congestion and pollution. In other words, whatever be the transport system, people will move but the modes they choose and the manner in which they travel will tend to be unsafe and inefficient without careful articulation and planning. This paper is essentially a status paper arguing for greater attention to policy making and its implementation.

\section{Urbanization pattern in India}

India's urban population is growing at an average rate of around 3 percent per annum. It has almost doubled during the period between 1981 and 2001 from 160 million to 285 million (Figure 1). The average rate of growth of the urban population is not expected to change significantly during next twenty years. Assuming decadal increase of around $37 \%$, India's urban population is expected to be around 540 million during 2021. In terms of percentage of total population, the urban population has gone up from $17 \%$ in 1951 to $29 \%$ in 2001 and is expected to increase up to around $37 \%$ by the year 2021 (Figure 2). Consequently, the number and size of cities have also increased considerably.

During the 1990s, 68 million people joined the ranks of urban dwellers - which imply a slower decadal growth of 31 percent when compared to the growth of 36 percent during 1980s. Although urbanization has slowed down in India during the 1990s, the number of metropolitan cities - those with a million plus population - has increased over this period. From 23 in 1991, the number of metropolitan rose to 35 according to the Census of India, 2001. India's metropolises grew rapidly during the 1990s with Surat registering the fastest growth of 85.1 percent followed by Faridabad (70.8 percent), Nashik (58.8 percent), Patna (55.3 percent), Jaipur (53.1 percent), Delhi (51.9 percent), Pune (50.6 percent), and Indore (47.8 percent). ${ }^{2}$ The overall decadal growth rate of the 35 metropolises worked out to be around 34 percent, which is higher than urban India's growth of 31 percent. India's big cities now account for a larger share of total urban population - a trend that has been observed since Independence. In 2001, the

\footnotetext{
${ }^{1}$ Supra note no. 1.

${ }^{2}$ Mohan, N. C., (2001), “The Paradox of Urbanisation”, The Financial Express, July $26^{\text {th }}$.
} 
share of metropolitan cities was 37.8 percent, up from 32.5 percent in 1991 and 26.4 percent in 1981.

Figure 1: Urban Population in India.

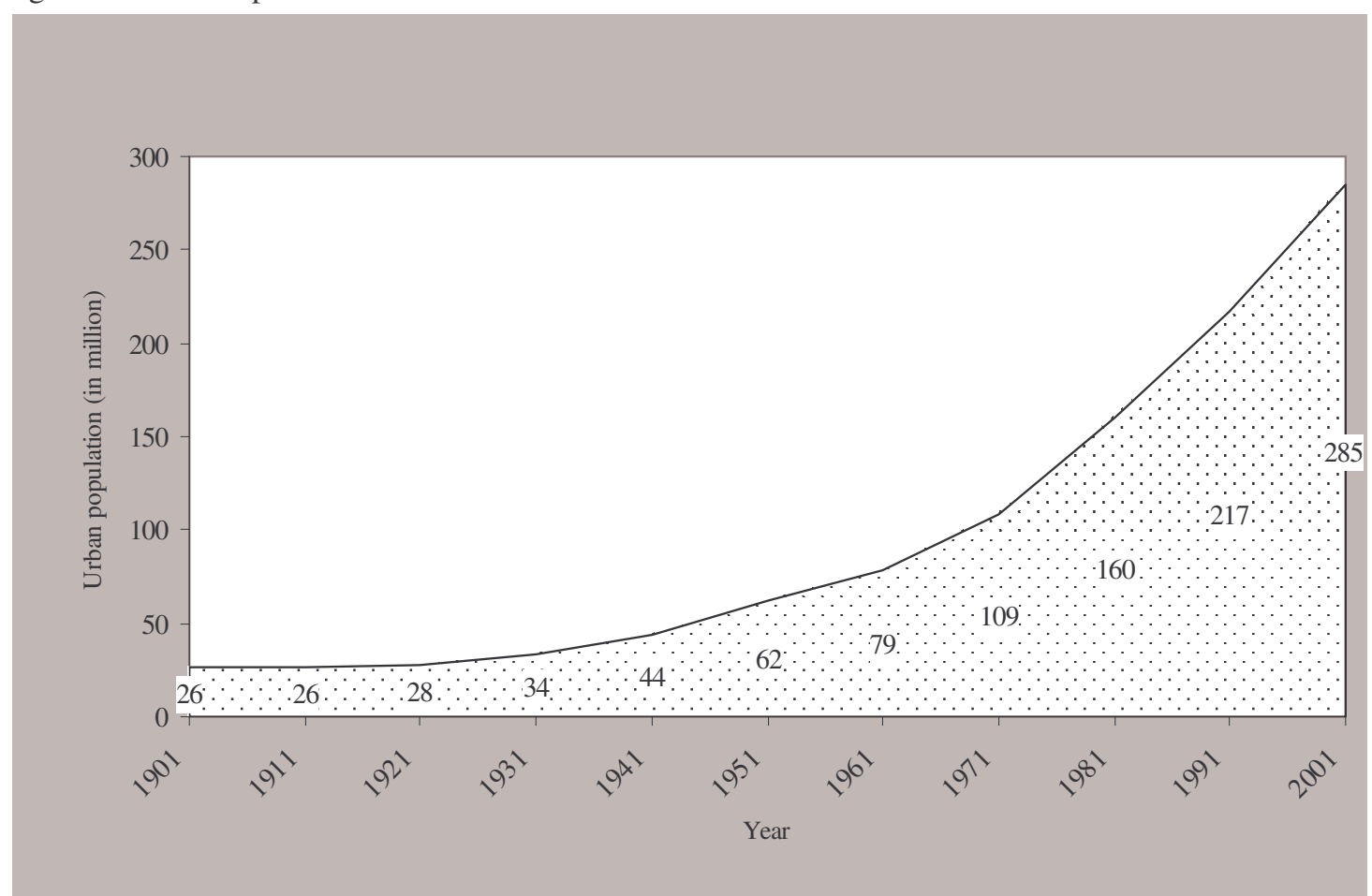

Sources: (1) Census of India 1991. Registrar General \& Census Commissioner, Ministry of Home Affairs, Government of India, New Delhi. (2) Mohan, N. C., (2001).

Figure 2: Share of urban population in India.

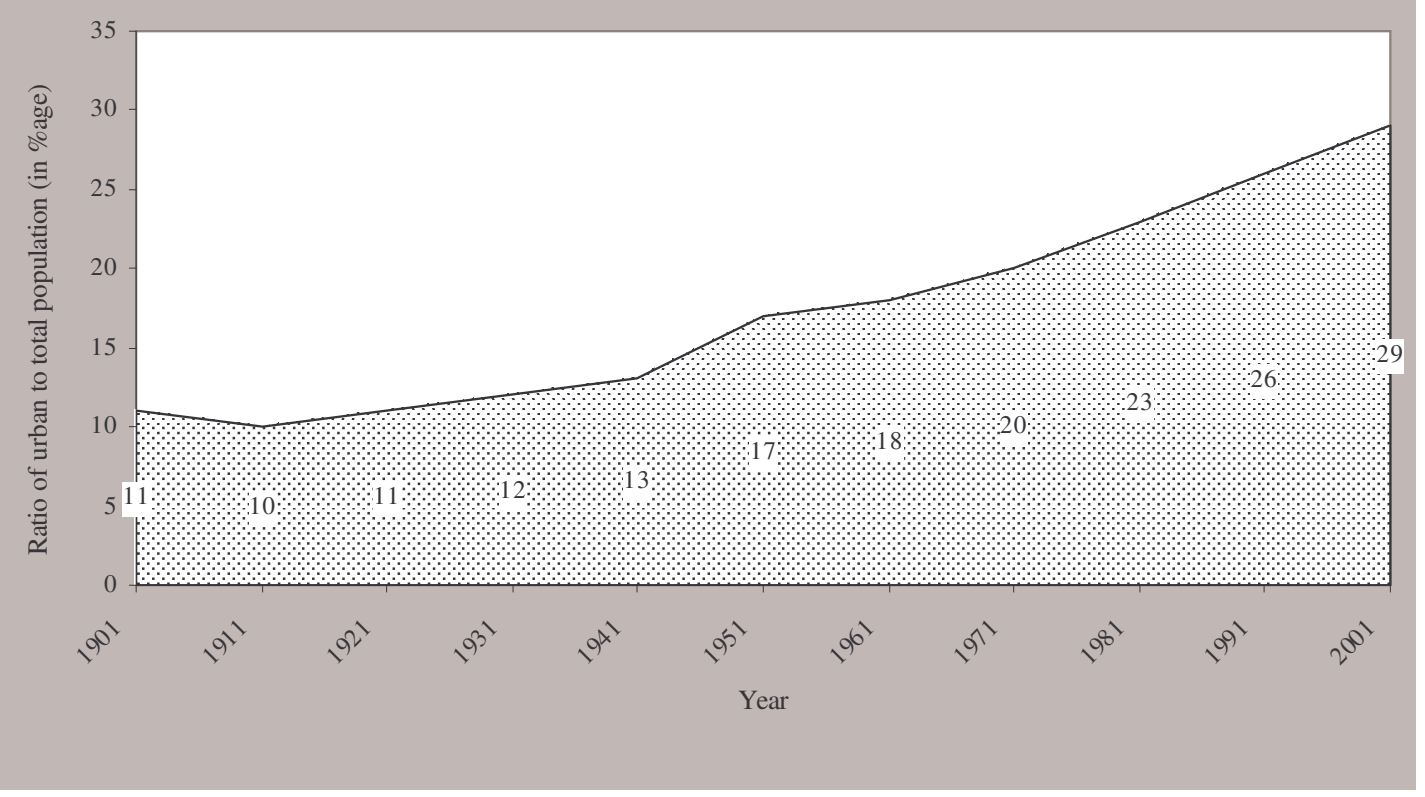

Sources: (1) Census of India 1991. Registrar General \& Census Commissioner, Ministry of Home Affairs, Government of India, New Delhi. (2) Mohan, N. C., (2001). 
The pattern of urbanization has many distinguishing characteristics. There is a great variation across states. The range is from around $8 \%$ for Himachal Pradesh to around $35 \%$ for Maharashtra. ${ }^{3}$ Many factors contribute to this variation. Transport is one of them. It is interesting to note that the level of economic development is higher in those states where urbanization level is high indicating a positive correlation between urbanization and economic development.

The distribution of urban population by city size widely varies and is skewed towards larger cities. One specific feature of India's urbanization is the increasing metropolitanization, that is, growth in the number and size of cities with a million plus population. The trends indicate the continued urbanization and metropolitaniztion in the years to come.

\section{Urbanization - inevitable and desirable}

The urbanization pattern and trends raise a number of issues. There is a debate as to whether it is an index of development or distress. The very process of urbanization has often been looked as something undesirable. While the objections used to be on social and moral grounds earlier, the criticism lately is more on economic grounds such as provision of requisite infrastructure and civic amenities at rapidly escalating per capita costs. Despite all the objections, the rate of urbanization has not even retarded, not to speak of its being halted. Certain inevitability about the process is being accepted steadily. It is felt that urbanization is necessary for the benefits of sharing modern technology for the growth and development of the entire national economy. In India, urban areas contribute more than sixty percent of the national income. It is expected that they will assume greater economic importance in the coming years.

Until recently policies towards urban areas have often been apologetic. The focus has been on rural areas where the poorest of the poor were said to live, and from where, it was argued agriculture-led growth must emanate. It was also argued that cities should be restricted in size, and action to tackle their problems should be limited to avoid increasing their attraction. This strategy was directed to limit migration towards cities and thereby promoting growth and balanced development of the country. Several facts reveal the weaknesses of this approach, which lead to a reappraisal of the strategy. It is clear that the ambiguity, which often underpinned discussion on urban policy, is presently undergoing rapid change towards a new and positive stance.

\section{Urban transport and city efficiency}

Many cities in India have grown at an unprecedented rate in recent years, and this growth is expected to continue in the foreseeable future. In 1951 only five cities in India had populations in excess of 1 million: Kolkata (4.67 million), Mumbai (2.97 million), Delhi (1.43 million), Chennai (1.54 million), and Hyderabad (1.13 million). By 2001, however, there are 35 cities in India whose population topped 1 million, and by the end of the year 2021 they are expected to be at least fifty.

Fast-growing cities in India have nurtured business and industry and have provided jobs and higher incomes to many migrants from rural areas. Thus, it is important that

\footnotetext{
3 Ranganathan, N., (1995), "National Urban Transport Policy - A Framework", Indian Journal of Transport Management, Vol. 19, No. 2, pp. 85-98.
} 
cities function efficiently - that their resources are used to maximize the cities' contribution to national income. Economic efficiency of cities and well-being of urban inhabitants are directly influenced by mobility or the lack of it. City efficiency largely depends upon the effectiveness of its transport systems, i.e., efficacy with which people and goods are moved throughout the city. Poor transport systems stifle economic growth and development, and the net effect may be a loss of competitiveness in both domestic as well as international markets.

Although Indian cities have lower vehicle ownership rate (number of vehicles per capita) than their counterparts in developed countries, they suffer from worse congestion, delay, accidents, air and noise pollution, energy wastage etc. than cities in industrialized countries. In Kolkata, for example, average speed during peak hours in Central Business District (CBD) area goes down as low as around $10 \mathrm{kms}$ per hour. This indicates both the amount of time and energy that are wasted and the scale of opportunity for improvement.

Public transport systems in Indian cities have not been able to keep pace with the rapid and substantial increases in demand over the past few decades. Bus services in particular have deteriorated, and their relative output has been further reduced as passengers have turned to personalized modes and intermediate public transport, adding to traffic congestion which has had its impact on quality as well. It is often thought to be inegalitarian to provide special services such as air-conditioned buses, express buses, and premium or guaranteed seats in return for higher fares. Experience shows that the public welcomes a wide choice of transport, but despite the clear need for greater variety in public transport, there is a tendency in established monolithic corporations to offer very limited choice.

Spending on transport is too often influenced by notion of political prestige than by rational calculations of economic growth. Most Indian cities spend too much on politically attractive but costly facilities, such as elevated roadways and mass rail transit systems, instead of making modest labor-intensive road improvements, extending city streets, and promoting low-cost bus operations. As per a World Bank Study, the money spent building just a few meters of subway could be used instead to construct or upgrade several miles of streets. ${ }^{4}$

The city cannot afford to cater only to the private cars and two-wheelers and there has to be a general recognition that without public transport cities would be even less viable. Much needs to be done if public transport is to play a significant role in the life of a city. Measures need to be taken in the short-run to enhance the quality of public transport service and to impose constraints on the use of private vehicles in cities. In the long-run, there needs to be effective land use planning and the introduction of new transit systems to keep the city moving. It must not be forgotten that cities are the major contributors to economic growth and movement in and between cities is crucial for improved quality of life. $^{5}$

\section{Current urban transport scenario in India}

On an average, during peak hours in Mumbai, the actual occupancy in a suburban train is in excess of 4000 passengers, which have maximum desirable capacity of 2600

\footnotetext{
${ }^{4}$ World Bank, (1986), “Urban Transport, a World Bank Policy Study”, World Bank, Washington, D.C.

${ }^{5}$ Supra note no. 1.
} 
passengers. ${ }^{6}$ Most of the Indian cities have more or less similar demand supply mismatch. Estimates for the metropolitan cities show that approximately 80 million trips will need to be catered per day whereas, only 37 million trips are being provided by the available rail and bus mass transport facilities. ${ }^{7}$ Furthermore, as per a World Bank study, for every extra one million people in a developing city an extra 3.5 to 4 million public transport trips per day are generated. ${ }^{8}$ Considering the population growth in most Indian cities, the urban transport infrastructure thus needs to be increased manifold in the decade or so, if the gap in the demand and supply has to be eliminated.

\subsection{Vehicular growth}

According to Motor Transport Statistics ${ }^{9}$, the annual rate of growth of motor vehicles in India is around 10 percent during last decade (see also Figure 3). In 1991 there were 21.7 million vehicles. After 10 years in 2001, this number increased by nearly three times to 55 million. The basic problem is not the number of vehicles in the country but their over concentration in a few selected cities, particularly in metropolitan cities. If one compares the vehicle as well as car ownership rate across countries, India fares poorly vis-à-vis even most developing countries. India, where more than $15 \%$ of the world's human population lives, constitutes just 5\% of the world's motor vehicle population. As far as cars are concerned, its share is even less than $1 \%$.

Figure 3: Motor vehicle population in India; 1951 to 2002.

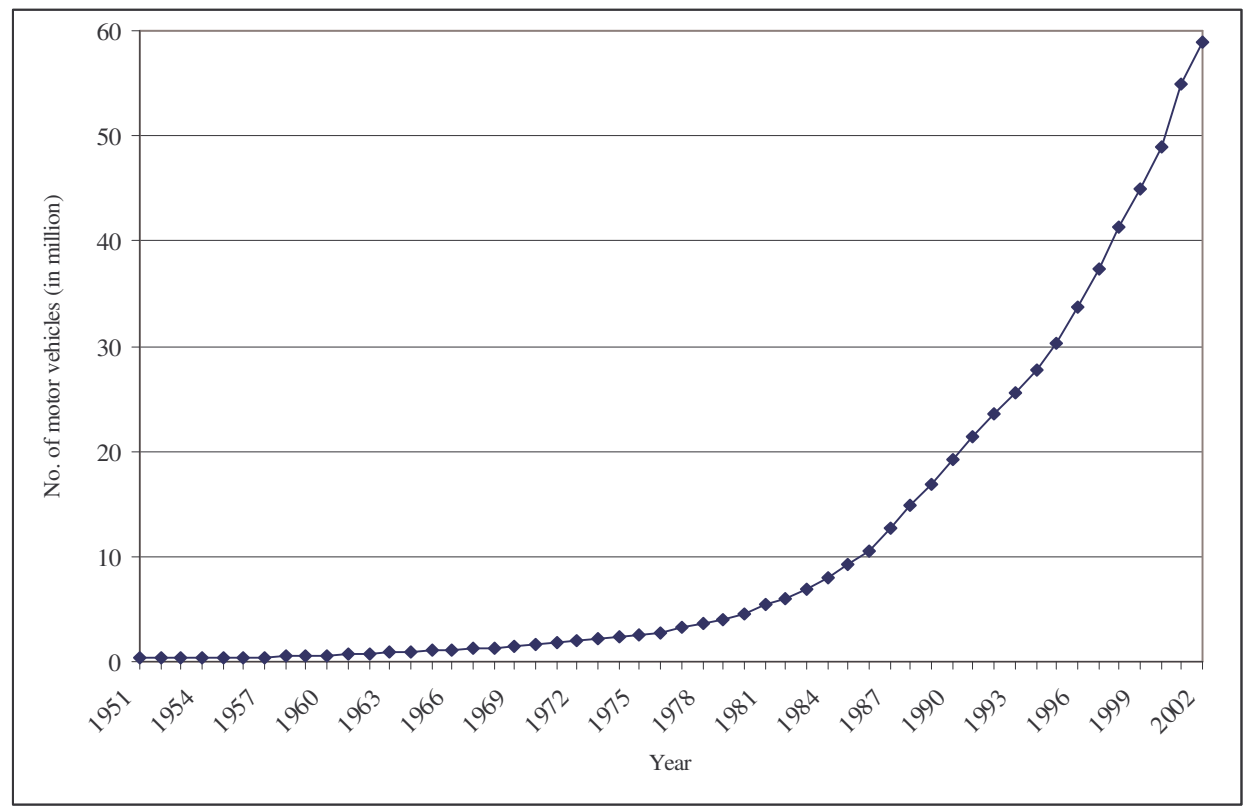

Source: Motor Transport Statistics of India, (Various Issues), Transport Research Wing, Ministry of Road Transport \& Highways, Government of India, New Delhi.

\footnotetext{
${ }^{6}$ Draft Regional Plan for Bombay Metropolitan Region 1996-2011, (1995), Bombay Metropolitan Regional Development Authority.

7 Traffic and Transportation Policies and Strategies in Urban Areas in India, (1998), Final Report, Ministry of Urban Development, Government of India, New Delhi.

${ }^{8}$ Supra note no. 5 .

9 Motor Transport Statistics of India, (Various Issues), Transport Research Wing, Ministry of Road Transport \& Highways, Government of India, New Delhi.
} 
Figure 4: Share of two wheelers, cars, and buses in total motor vehicle population in India.

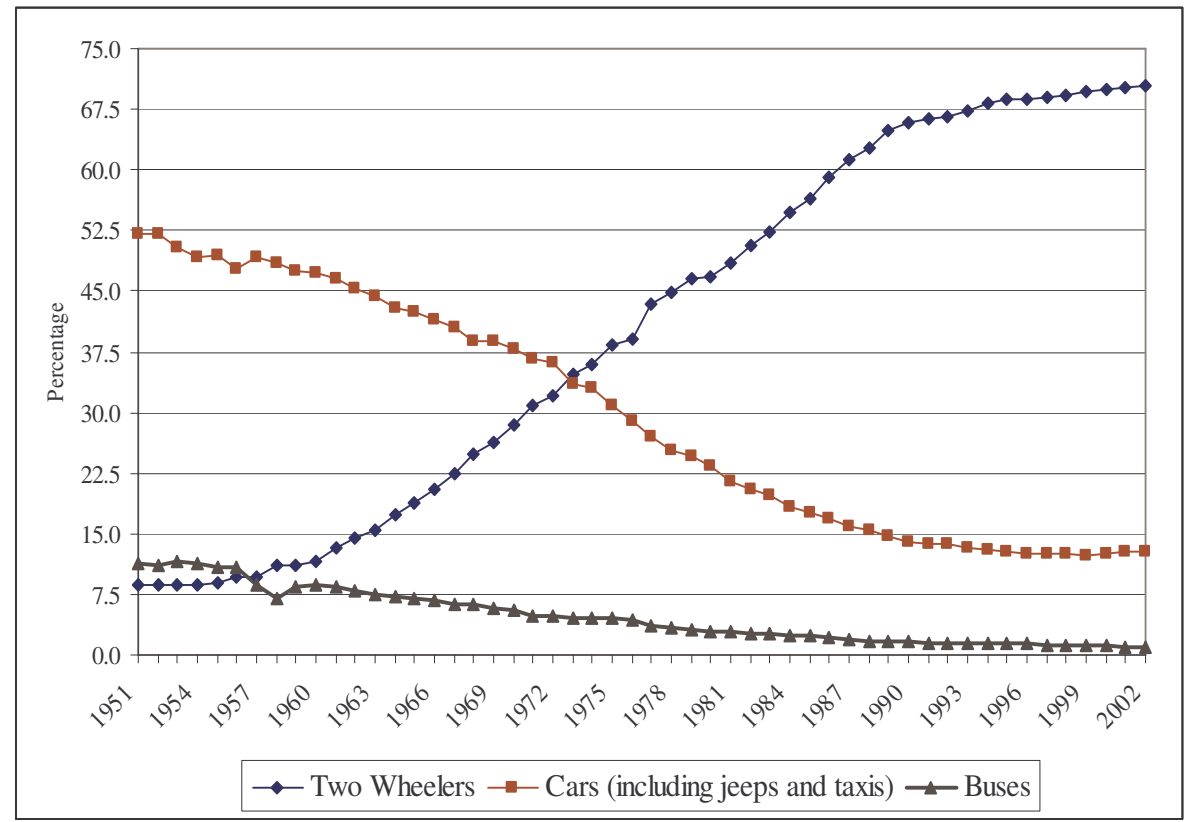

Source: Motor Transport Statistics of India, (Various Issues), Transport Research Wing, Ministry of Road Transport \& Highways, Government of India, New Delhi.

The share of buses is negligible in most Indian cities when compared to two-wheelers and cars. For example, two-wheelers and cars together constitute more than $91 \%$ in Kanpur, $88 \%$ in Hyderabad, and $86 \%$ in Nagpur whereas buses constitute 0.5, 0.5, and 0.4 percent respectively. ${ }^{10}$ The result is decline in the percentage share of buses from 11.1 percent in 1951 to 1.02 percent in 2001 at all India level.

In the absence of an adequate and efficient public transport, a large number of private and para-transit modes have entered into the market to meet the travel demand. Such a proliferation of vehicles results in acute congestion, inordinate delays, serious accidents, high-energy consumption particularly of fossil fuels, and intense pollution of the environment.

\subsection{Travel demand}

The level of urban travel demand in India is increasing substantially over the years. Three factors contribute to this. The first is the increase in population. The urbanization process has indicated that the population size of an urban area doubles in about two decades. The second factor is the mobility rate, that is, average trips per person per day. Mobility rate in urban India is continuously increasing over the years. For example, in Delhi, average number of trips per person per day have increased from 0.49 during 1969 to 1.10 during 2001 (Table 1). The trip rate for Mumbai, Kolkata, Chennai, Hyderabad, Bangalore, Ahmedabad, and Pune are 1.26, 1.26, 1.22, 1.05, 1.20, 1.57, and 1.48 respectively. ${ }^{11}$ The third factor contributing to travel demand is the increase in trip length due to increase in the physical expansion of the city. For example, the average

\footnotetext{
${ }^{10}$ Supra note no. 8.

${ }^{11}$ Report of the Working Group on Urban Transport, (1996), Ministry of Urban Affairs and Employment, Government of India, New Delhi.
} 
trip length in Delhi has increased from $5.4 \mathrm{kms}$ in 1969 to about $13.5 \mathrm{kms}$ in 2001. Currently, it is estimated that average trip length of four mega cities varies from 12.7 to $13.5 \mathrm{kms}$. There is also change in the pattern of trip distribution; more and more trips are being made in urban areas for work followed by education. For example, more than $60 \%$ of the total trips in Mumbai are meant for work and around $31 \%$ for education. ${ }^{12}$

Table 1: Average number of trips per person per day in Delhi.

\begin{tabular}{l|ccc}
\hline Purpose & 1969 & 1981 & 2001 (Estimated) \\
\hline Work & 0.29 & 0.35 & 0.45 \\
Education & 0.08 & 0.10 & 0.15 \\
Others & 0.12 & 0.27 & 0.50 \\
All purpose & 0.49 & 0.72 & 1.10 \\
\hline
\end{tabular}

Source: Ranganathan, N. (1995).

The serious consequence of such development is a steep rise in demand for transport in almost all the cities in India. Table 2 presents desired shares of mass transport in Indian cities on the basis of their population levels. While the share of mass transport is well below the desired range, the share of personalized transport and para transit is already above the optimal range (Table 3). What is worse is that the modal split appears to be moving in the wrong direction. For example, share of mass transit in Delhi has stayed at the same low and unacceptable level for the last two decades (Table 4). Since its population is more than 10 million, mass transport should serve at least $75 \%$ of the total travel demand rather than the existing level of $62 \%$. In Lucknow, which has a population of about 2 million, bus transport plays a negligible role in providing mobility to urban dwellers (Table 5). Table 3 clearly shows that the Intermediate Public Transport (IPT) modes play a significant role in meeting the transport demand in small and medium size cities in the absence of adequate public transport system. Share of trips made by personalized modes, particularly two-wheelers is very high in virtually all the cities. Percentage of trips by bicycle is seen to decrease with increase in city size.

Table 2: Desirable modal split for Indian cities of various sizes (as a \%age of total trips by mechanical modes).

\begin{tabular}{l|ccc}
\hline City size range (pop. In & Mass transport & Bicycle & Other modes \\
\hline $0.1-0.5$ & $30-40$ & $30-40$ & $25-35$ \\
$0.5-1.0$ & $40-50$ & $25-35$ & $20-30$ \\
$1.0-2.0$ & $50-60$ & $20-30$ & $15-25$ \\
$2.0-5.0$ & $60-70$ & $15-25$ & $10-20$ \\
5.0 plus & $70-85$ & $15-20$ & $10-15$ \\
\hline
\end{tabular}

Source: Traffic and Transportation Policies and Strategies in Urban Areas in India, (1998), Final Report, Ministry of Urban Development, Government of India, New Delhi.

${ }^{12}$ Supra note no. 12. 
European Transport $\backslash$ Trasporti Europei n. 27 (2004): 26-44

Table 3: Existing modal split in Indian cities during 1994 (in \%age).

\begin{tabular}{lccccccc}
\hline \begin{tabular}{l} 
City $\begin{array}{l}\text { population } \\
\text { (in million) }\end{array}$ \\
\hline $0.10-0.25$
\end{tabular} & Walk & $\begin{array}{c}\text { Mass } \\
\text { transport }\end{array}$ & $\begin{array}{c}\text { IPT } \\
\text { Fast Slow }\end{array}$ & Car & $\begin{array}{c}\text { Two } \\
\text { wheeler }\end{array}$ & Bicycle & Total \\
$0.25-0.50$ & 37.8 & 20.6 & 8.917 .2 & 2.6 & 29.8 & 20.9 & 100.0 \\
$0.50-1.0$ & 30.7 & 25.4 & 8.212 .0 & 9.5 & 29.1 & 15.9 & 100.0 \\
$1.0-2.0$ & 29.6 & 30.6 & 6.48 .1 & 3.3 & 39.6 & 12.1 & 100.0 \\
$2.0-5.0$ & 28.7 & 42.3 & 4.93 .0 & 5.0 & 28.9 & 15.9 & 100.0 \\
5.0 plus & 28.4 & 62.8 & 3.33 .7 & 6.1 & 14.8 & 9.4 & 100.0 \\
\hline
\end{tabular}

Source: Traffic and Transportation Policies and Strategies in Urban Areas in India, (1998), Final Report, Ministry of Urban Development, Government of India, New Delhi.

Table 4: Modal split trend in Delhi.

\begin{tabular}{|c|c|c|c|c|}
\hline \multirow[t]{2}{*}{ Mode } & \multicolumn{4}{|c|}{ Modal split (in percent) } \\
\hline & 1969 & 1981 & 1986 & 1994 \\
\hline Bus & 41 & 62 & 62 & 62.0 \\
\hline Car & & & & 6.9 \\
\hline Two-wheeler & & & & 17.6 \\
\hline Bicycle & 59 & 38 & 38 & 6.6 \\
\hline Cycle & & & & 3.5 \\
\hline Others & & & & 3.4 \\
\hline
\end{tabular}

Source: Singal, B. I., (2000).

Table 5: Modal split trend in Lucknow.

\begin{tabular}{l|ccc}
\hline Mode & \multicolumn{3}{|c}{ Modal split (in percent) } \\
\cline { 2 - 4 } Bus & $1963-64$ & $1984-85$ & $1997-98$ \\
Car & 2.6 & 3.4 & 4.3 \\
Two-wheeler & 1.1 & 1.3 & 3.4 \\
Tempo & 0.8 & 8.2 & 26.7 \\
Bicycle & - & 4.6 & 9.2 \\
Cycle & 26.3 & 30.1 & 23.4 \\
Other & 2.8 & 16.8 & 14.9 \\
Walk & 0.2 & 2.7 & 0.4 \\
\hline
\end{tabular}

Source: Singal, B. I. (2000).

Note: (-) indicates unavailability of data. 


\subsection{Existing transport infrastructure}

The percentage of space used for transportation in cities in India is far less when viewed in comparison to its counterparts in the developed world. In general, the road space in Indian cities is grossly insufficient. To make the situation worse, most of the major roads and junctions in Indian cities are heavily encroached by parked vehicles, roadside hawkers, and pavement dwellers. As a consequence of these factors, the already deficient space for movement of vehicles is further reduced. ${ }^{13}$ Even though urbanization has been growing rapidly in India, little attention has been paid to urban mass transport systems. The present urban rail services in India are extremely limited. Bus transit is the backbone of urban transport in most metropolitan cities except a few where it has never developed to be a significant mode (e.g., Lucknow where the share of person trips by public transit is less than 5 percent). Services are mostly run by publicly owned state transport undertakings. Qualitatively, the available transport services are overcrowded, unreliable, and involve long waiting periods. As a result, there is a massive shift to personalized transport, specially two-wheelers and also proliferation of various types of intermediate public transport modes such as three-wheeler autorickshaws, taxis and mini-buses. In almost all metropolitan cities in India, intermediate public transport provides a viable supplement to buses and suburban rail. People in upcoming urban areas rely heavily on auto-rickshaws and taxis for transportation.

\section{Road safety in india}

Many developing countries including India have serious road accident problems. Fatality rates are quite high in comparison with developed countries. While in Europe and North America the situation is generally improving, many developing countries face a worsening situation. A large number of deaths in developing world are due to road accidents. Apart from the humanitarian aspects of the problem, road accidents cost countries of developing world at least one percent of their Gross National Product (GNP) each year - sums they can ill-afford to lose. ${ }^{14}$ The nature of the problem in developing countries is in many ways different from that in the industrialized world. The proportion of commercial and public service vehicles involved in road accidents are often much greater. Pedestrians and cyclists are often the most vulnerable. Given the fact that the poorest of the poor in urban India cannot even afford to use public transport, they resort to cycling or walking. Since cyclists and pedestrians are the prime victims of the road accidents, there must be a serious attempt to either make public transport available to them through targeted subsidization or to make the road safer to cycle and walk.

During the year 2002, nearly 85,000 people died due to road accidents in India (Figure 5). Fatality risk (defined as, road accidental deaths per million population) in India is increasing over the years, from 64 in 1990 to 80 in 2002. During the same period, road accidental deaths have increased at a rate of 3.8 percent per annum while the population of the country has increased by only 1.8 percent per annum. Although

\footnotetext{
${ }^{13}$ Supra note no. 1.

${ }^{14}$ Ghee, C., et al., (1997), "Socio Economic Aspects of Road Accidents in Developing Countries", TRL Report, TRL 247, Transport Research Laboratory, Crowthorne.
} 
fatality rate (defined as, number of fatalities per 10,000 vehicles) in India is declining over the years, it is still quite high in comparison to developed world.

Figure 5: Rate of road accidental deaths in India.

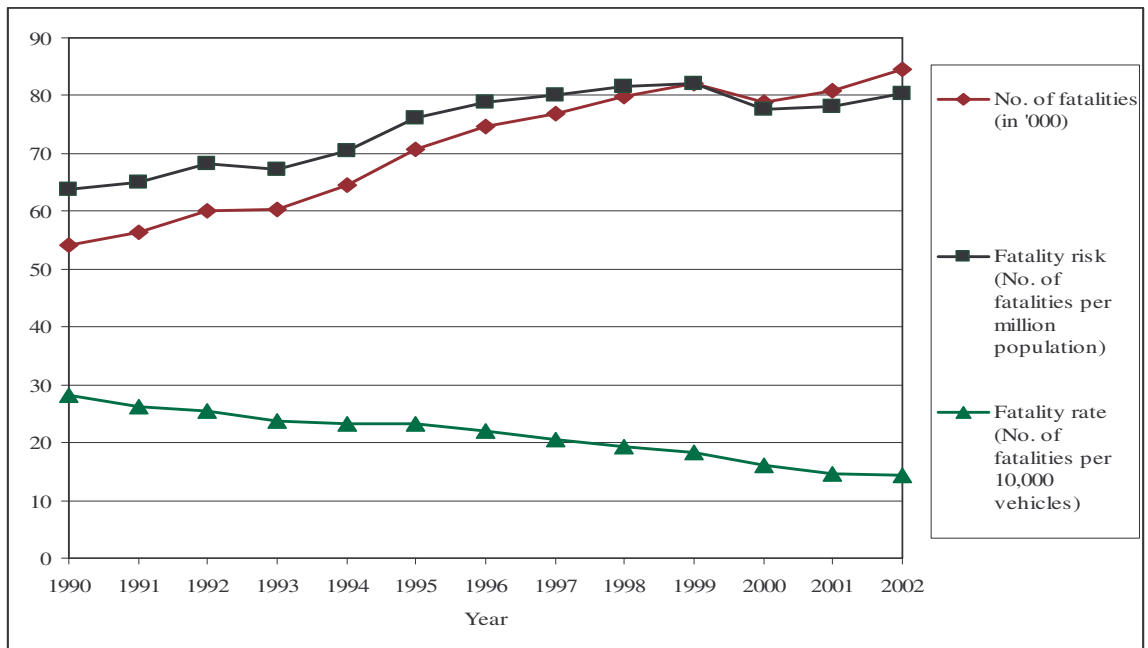

Source: Accidental Deaths \& Suicides in India, (Various Issues), National Crime Records Bureau, Ministry of Home Affairs, Government of India, New Delhi.

Although, Indian national highways are notorious for road accidents, there are serious road safety problems in Indian cities as well. It is alarming to note that more than 38 people die per week due to road accidents in Delhi alone. Between the year 1990 and 2000, number of road accidental casualties has increased in almost all the metropolitan cities in India (Table 6). Analysis of Table 6 shows that except Kolkata, Mumbai, and Nagpur all sample cities are showing very high growth rate in fatalities over the sample period. Accident severity index (defined as, number of fatalities per 100 accidents) is also very high for all the sample cities other than Ahmedabad, Bangalore, Kolkata, and Mumbai.

Table 6: Road accidental casualties in selected metropolitan cities in India.

\begin{tabular}{l|cccccc}
\hline Metropolitan & \multicolumn{4}{|c}{1990} & & \multicolumn{3}{c}{2000} \\
\cline { 2 - 7 } cities & Fatalities & Accidents & ASI & Fatalities & Accidents & ASI \\
Ahmedabad & 195 & 2873 & 7 & 223 & 3014 & 7 \\
Bangalore & 562 & 6729 & 8 & 659 & 8391 & 8 \\
Chennai & 507 & 5877 & 9 & 692 & 4878 & 14 \\
Delhi & 1670 & 7697 & 22 & 1989 & 10245 & 19 \\
Hyderabad & 276 & 1412 & 20 & 425 & 2492 & 17 \\
Jaipur & 235 & 1062 & 22 & 312 & 2474 & 13 \\
Kolkata & 463 & 10911 & 4 & 452 & 11036 & 4 \\
Mumbai & 400 & 25331 & 2 & 449 & 26450 & 2 \\
Nagpur & 166 & 1139 & 15 & 255 & 1569 & 16 \\
Pune & 275 & 1387 & 20 & 306 & 2384 & 13 \\
\hline
\end{tabular}

Source: State Transport Undertakings - Profile and Performance, (Various Issues), Central Institute of Road Transport, Pune, India.

Note: ASI indicates Accident Severity Index (defined as, number of fatalities per 100 accidents). 


\section{Environmental impact of urban transport}

The Indian metropolitan cities are facing serious environmental problem due to the growing air pollution caused by fuels used in vehicles. For example, 72\% of air pollution in Delhi is caused by vehicular emission. ${ }^{15}$ Atmospheric pollutants commonly associated with motor vehicles are nitrogen oxides, hydrocarbons, carbon monoxide, sulphur oxides, lead, and Suspended Particulate Matter (SPM). The ambient air pollution in terms of Suspended Particulate Matter (SPM) in all metropolitan cities in India exceeds the limit set by World Health Organization. ${ }^{16}$ For example, in Kolkata, the average annual emission of SPM is 394 microgrammes per cubic meter while the World Health Organization standard is $75 .^{17}$ In fact, air pollution in many of India's cities has become atrocious, and has already had serious health effects, especially in the form of respiratory diseases.

There is a direct relationship between transport system and air pollution in a city. Vehicular emissions depend on vehicle-km, vehicle speed, age of vehicle, and of course emission rate of different vehicle categories. The average peak hour speed in Indian cities is far less than the optimum one. According to Centre for Science and Environment (CSE), the quantity of all the three major air pollutants (namely, nitrogen oxides, hydrocarbons, and carbon monoxide) drastically increases with reduction in motor vehicle speeds. For example, at a speed of $75 \mathrm{kmph}$, emission of carbon monoxides is $6.4 \mathrm{gm} / \mathrm{veh} .-\mathrm{km}$, which increases by five times to $33.0 \mathrm{gm} / \mathrm{veh} .-\mathrm{km}$ at a speed of $10 \mathrm{kmph}$. Similarly, emission of other pollutants increases with the reduction in vehicle speed. Thus, traffic congestion not only increases the delay but also increase the pollution level. ${ }^{18}$ Table 7 presents emission factors for different types of vehicles, under typical conditions, in Indian cities. One can see that emission rate, defined as quantity of pollutants emitted per vehicle-km, pertaining to carbon monoxide and hydrocarbons is very high for personalized modes (e.g., cars and two-wheelers) and para transit modes (e.g., three-wheelers) in comparison to buses, trucks, and Light Commercial Vehicles (LCVs). With deteriorating level of mass transport services and increasing use of personalized motor vehicles, vehicular emission is assuming serious dimensions in most of the Indian cities (see also Table 8).

Table 7: Emission rate of different vehicles in a typical Indian city (in gms/km).

\begin{tabular}{l|cccccc}
\hline Vehicle & $\mathrm{CO}$ & $\mathrm{HC}$ & $\mathrm{NO}_{\mathrm{x}}$ & $\mathrm{SO}_{2}$ & $\mathrm{~Pb}$ & $\mathrm{TSP}$ \\
\hline Two-wheeler & 8.30 & 5.18 & - & 0.013 & 0.004 & - \\
Car & 24.03 & 3.57 & 1.57 & 0.053 & 0.012 & - \\
Three-wheeler & 12.25 & 7.77 & - & 0.029 & 0.009 & - \\
Bus & 4.38 & 1.33 & 8.28 & 1.441 & - & 0.275 \\
Truck & 3.43 & 1.33 & 6.48 & 1.127 & - & 0.450 \\
LCV & 1.30 & 0.50 & 2.50 & 0.400 & - & 0.100 \\
\hline
\end{tabular}

Source: Sibal, V., and Y., Sachdeva, (2001).

Note: (-) indicates negligible quantity.

15 Economic Survey of Delhi 1999-00, (2000), Planning Department, Government of NCT of Delhi, India.

16 Sharma, N. P., and S., Mishra, (1998), "Transport for Healthy Tomorrow, Issues and Options", Presented during the Seminar on Planning Delhi: Healthy City in the next Millennium, DRC, ITPI, New Delhi, 1998.

${ }^{17}$ Supra note no. 1.

${ }^{18}$ Supra note no. 1. 
Table 8: Estimated vehicular emission load in selected metropolitan cities in India.

\begin{tabular}{l|cccccc}
\hline $\begin{array}{l}\text { Name } \\
\text { the city }\end{array}$ & \multicolumn{5}{|c}{ Vehicular pollution load (tonnes per day) } \\
\cline { 2 - 7 } & Particulates & $\begin{array}{c}\text { Sulphur } \\
\text { dioxide }\end{array}$ & $\begin{array}{c}\text { Oxide of } \\
\text { the } \\
\text { Nitrogen }\end{array}$ & Hydrocarbons & $\begin{array}{c}\text { Carbon } \\
\text { monoxide }\end{array}$ & Total \\
Delhi & 10.30 & 8.96 & 126.46 & 249.57 & 651.01 & 1046.30 \\
Mumbai & 5.59 & 4.03 & 70.82 & 108.21 & 469.92 & 659.57 \\
Banglore & 2.62 & 1.76 & 26.22 & 78.51 & 195.36 & 304.47 \\
Kolkata & 3.25 & 3.65 & 54.69 & 43.88 & 188.24 & 239.71 \\
Ahmedabad & 2.95 & 2.89 & 40.00 & 67.75 & 179.14 & 292.71 \\
Pune & 2.39 & 1.28 & 16.20 & 73.20 & 162.24 & 255.31 \\
Chennai & 2.34 & 2.02 & 28.21 & 50.46 & 143.22 & 226.25 \\
Hyderabad & 1.94 & 1.56 & 16.84 & 56.33 & 126.17 & 202.84 \\
Jaipur & 1.18 & 1.25 & 15.29 & 20.99 & 51.28 & 88.99 \\
Kanpur & 1.06 & 1.08 & 13.37 & 22.24 & 48.42 & 86.17 \\
Lucknow & 1.14 & 0.95 & 9.68 & 22.50 & 49.22 & 83.49 \\
Nagpur & 0.55 & 0.41 & 5.10 & 16.32 & 34.99 & 57.37 \\
Grand total & 35.31 & 29.84 & 422.88 & 809.96 & 2299.21 & 3597.20 \\
\hline
\end{tabular}

Source: Urban Statistics, (1996), Central Pollution Control Board, New Delhi, India.

\section{Energy consumption in the transport sector}

In general, energy consumed in urban transport sector are petroleum products mainly gasoline and High Speed Diesel (HSD). The energy consumption in urban transport largely depends on the modal split as well as speed of the vehicle. On an average, energy consumption per pass.-km by bus is the least and by car is the highest among different modes of road-based passenger transport (last column of Table 9). Estimated energy consumption in urban India during 1994 is presented in Table 10. On an average, a car consumes nearly six times more energy than an average bus to provide passenger mobility (in terms of pass.-km), while two-wheelers consume about 2.5 times and threewheelers 4.7 times more energy (last column of Table 9). In terms of fuel cost per pass.$\mathrm{km}$, a two-wheeler is 6.8 times, three-wheeler 7.0 times, and a car is 11.8 times costlier than a bus. Furthermore, a car occupies over 38 times more road space in comparison to a bus to provide same level of passenger mobility (in terms of pass.-kms). The corresponding figures for two- and three-wheelers are 54 and 15 respectively. This shows that bus transportation is not only favorable in terms of environmental consideration but also in terms of energy efficiency and best possible use of scarce road space.

Table 9: Energy efficiency of various modes of passenger transport.

\begin{tabular}{l|cccc}
\hline Mode & Fuel type & $\begin{array}{c}\text { Fuel efficiency } \\
(\mathrm{Km} / \text { litre })\end{array}$ & $\begin{array}{c}\text { Operating energy } \\
\text { intensity (litre/PKm) }\end{array}$ & $\begin{array}{c}\text { Relative energy } \\
\text { efficiency }\end{array}$ \\
\hline Bus & Diesel & 4.30 & 0.006 & 1.00 \\
Two-wheeler & Petrol & 44.40 & 0.015 & 2.50 \\
Three-wheeler & Petrol & 20.00 & 0.028 & 4.70 \\
Car & Petrol & 10.90 & 0.038 & 6.30 \\
\hline
\end{tabular}

Source: Sibal, V. and Sachdeva, Y. (2001). 
Table 10: Estimated annual energy consumption in urban India during 1994.

\begin{tabular}{l|cccccccc}
\hline $\begin{array}{l}\text { City size } \\
\text { (Pop. in }\end{array}$ & $\begin{array}{c}\text { No. } \\
\text { of } \\
\text { million) }\end{array}$ & \multicolumn{6}{c}{ Annual fuel consumption (in thousand tons) } \\
\cline { 3 - 9 } & cities & $\begin{array}{c}2- \\
\text { wheelers }\end{array}$ & $\begin{array}{c}\text { Cars/ } \\
\text { Jeeps }\end{array}$ & $\begin{array}{c}3- \\
\text { wheelers }\end{array}$ & Buses & Trucks & Rail & Total \\
$0.1-0.5$ & 281 & 567 & 325 & 74 & 546 & 857 & - & 2369 \\
$0.5-1.0$ & 34 & 215 & 198 & 52 & 230 & 405 & - & 1100 \\
$1.0-2.0$ & 15 & 402 & 150 & 41 & 162 & 203 & - & 958 \\
$2.0-5.0$ & 5 & 272 & 130 & 31 & 147 & 87 & - & 667 \\
5.0 plus & 5 & 403 & 373 & 51 & 528 & 213 & 6 & 1574 \\
Total & 340 & 1859 & 1176 & 249 & 1613 & 1765 & 6 & 6668 \\
\hline
\end{tabular}

Source: Traffic and Transportation Policies and Strategies in Urban Areas in India, (1998), Final Report, Ministry of Urban Development, Government of India, New Delhi.

Note: (-) indicates unavailability of data.

\section{Need for an urban transport policy}

Urban transportation is the single most important component instrumental in shaping urban development and urban living. While urban areas may be viewed as engines of growth, urban transport is, figuratively and literally, the wheel of that engine. The test of urban governance depends upon the quality of life the city or town offers. ${ }^{19}$ Since transport is one of the prime determinants of quality of life, it is for the government to articulate the need for mobility and facilitate it through an appropriate mechanism. In fact, efficiency of cities greatly depends on the development of transport systems, as urban transport is a catalyst for overall development. However, the cities in India suffer from the absence of a cogent urban transport policy.

Urban transportation problems in India are manifested in the form of congestion, delay, accidents, energy wastage, and pollution. All these have very heavy economic, social, and environmental costs. The need of the hour is therefore a sound urban transport policy. The major thrust of such an urban transport policy should include integrated planning, an optimum share between public and private modes, choice of relevant technology for public transport systems, optimal use and management of available resources, restructuring of monetary and fiscal policy to encourage and promote public transport, and establishment of institutional arrangements, at all levels of governance, particularly at the city level, for planning, development, operation, management, and coordination of urban transport systems.

\section{Policy measures}

Road transport plays major role in providing passenger mobility in urban India. Although rail based transport services are available in few mega cities, they hardly play

\footnotetext{
${ }^{19}$ Padam, S. (2001), “Transport and Urban Governance”, Urban Transport Journal, Vol. 2, No. 1, pp. 3033.
} 
any role in meeting the transport demand in rest of the million plus cities. Considering the financial constraint in improving the rail-based mass transport system, it is evident that bus transport will have to play a major role in providing passenger transport services in Indian cities in the years to come. Bus transport is favorable over its other counterparts not only from energy efficiency but also from an environmental point of view. There is a need to maximize its potential by encouraging promotional measures. ${ }^{20}$

Although, attracting private vehicle owners to switch to bus transport is not easy, however, high quality bus transport services have proven to be quite successful in attracting users of para-transit modes such as auto-rickshaws and taxis. Therefore, there is a need to introduce variety of bus transport services in Indian cities to cater the need and demand of different segment. Given the opportunity, people reveal widely divergent transport preferences, but in many places city authorities favor a basic standard of bus services. Government regulation and control have exacerbated the poor operational and financial performance of the publicly owned STUs which are the main providers of passenger transport services. Generally, public transport services work most efficiently with a minimum government control. In particular, the freedom to set fares in response to market forces is more likely to mean that supply and demand balance each other. In addition, the freedom to determine the routes, size of vehicles, quality of services, frequency of services etc. enhances the likelihood of economic viability and public satisfaction. Too often unnecessary regulations discourage innovation, which results in limiting the range and quality of bus transport services. Furthermore, publicly owned urban bus transport undertakings in India often lack the flexibility of organization, the ability to hire and fire staff, or the financial discretion needed to adapt to changing conditions. In such circumstances, a policy, which encourages private participation in the provision of bus services, should be welcomed. One should note that under competition, operators tend to become more responsive to customers' needs and more innovative in finding ways to cut costs. Moreover, the alleged disadvantages of competition seldom are found to be real problems and if, they do arise, can usually be overcome by minimal regulatory intervention.

Considering the forecasts of rapid growth in urban travel demand, the need for bus services can be expected to intensify greatly in the years to come. If the private and the public sectors play their appropriate roles, most Indian cities will have the opportunity to develop vigorous and viable public transport systems. Because of rapid growth in travel demand, considerable expansion of public transport systems in most cities will be an absolute necessity. If a knowledge-based regulatory and planning authority for public transport is installed in every city, there can be a healthy coordination of private and public sectors, complementary rather than uneconomically competing with one another.

In general, Indian cities have not made much progress in implementing the demand side management measures, such as congestion pricing, restraints on parking etc. Although policy measures that involve restraining the use of private cars and twowheelers are likely to be unpopular, a gradualist approach of progressively introducing restraints on road use, while at the same time improving public transport, is more likely to lead to greater acceptance. It is believed that improved public transport and more efficient management of demand would help to combat the trend away from public transport vehicles towards greater use of personalized modes. ${ }^{21}$

\footnotetext{
${ }^{20}$ Supra note no. 1.

${ }^{21}$ Supra note no. 1.
} 
The transport system management strategy like one way traffic system, improvement of signals, bus priority lane etc. should be introduced in all cities especially in metropolitan cities so that the existing road capacity and road user safety is increased. Road infrastructure improvement measures like new road alignments, hierarchy of roads, provision of service roads, bye passes, ring roads, bus bays, wide medians, intersection improvements, construction and repair of footpaths and roads, removal of encroachments, good surface drainage etc. should also be introduced at least in metropolitan cities. In case of mega cities, it is essential to have long-term measures as well, involving technology upgradation and introduction of high speed, high capacity public transport system particularly along high-density traffic corridors. One should note that capital-intensive projects should be considered if and only if it is absolutely necessary. In many cases, instead of building underground railways or elevated highways, government would have done better to have increased the capacity of existing bus services through bus priority measures, such as exclusive busways and better road access. In some case, of course, capital-intensive investments, such as elevated highways or rapid rail systems, may be the best approach. However, there should be careful appraisal of all capital-intensive projects before implementing them. In addition, there should be determined effort to develop alternative pollution free fuels in the long run.

In many Indian cities, non-motorized vehicles are a major transport mode and source of employment for the poor. However, it is found that transport planning in Indian cities does not include non-motorized vehicles and pedestrians in its consideration. An urban transport policy should encourage the need for developing 'green' modes like bicycle, walk, provision of pedestrian paths and cycle tracks especially in new development areas of metropolitan cities.

All these measures suggested above would require a policy framework encompassing regulatory, pricing, and taxation mechanisms. They would have to be reinforced with effective enforcement to encourage the use of clean vehicles and fuels, restrict the use of polluting vehicles and fuels, and modify travel behavior and transport demand using regulatory and pricing instruments.

\section{Concluding remarks}

Urban transport situation in large cities in India is deteriorating. Commuters in these cities are faced with acute road congestion, rising air pollution, and a high rate of accident risk. It is no longer safe to walk on the road or to ride a bicycle. Mass transport is scarce, overcrowded, unreliable, and involves long walking periods. The transport crisis faced by most of the metropolitan cities in India harms business efficiency, threatens to undermine the city's competitive position, and worsen the people's quality of life. Without vigorous action, all of these problems would intensify, as rising population over the coming decades and the goal of growing economic prosperity put more pressure on the system. Achieving this requires not only overcoming chronic under-investment, but also a complete overhaul of public transport management. It is high time the decision-makers take necessary action to make cities viable.

The complexities of urban transport cannot be resolved without a concise and cogent policy. Urban areas, whether mega-cities, cities or towns, have grown and are growing. The demands they are making have remained largely unmet. The deteriorating quality of public transport is driving people to personalized transport, most of which are fuel- 
inefficient, congesting and unsafe. While it is not the intention of this paper to make a case against large capital intensive metro systems, the realities demand solutions which are within the reach. Bus as a mode of public transport, has a potential which is yet to be fully exploited. Given the priority that it deserves, bus can ensure safety, act against pollution and promote mobility for the poor and not the so poor.

In a nutshell, transport strategy should support the following objectives:

- Provide and promote sustainable high quality links for people, goods, and services to, from and within the city to benefit economic growth and environmental quality of city;

- Improve the efficiency and effectiveness of city's transport systems;

- Planning development in a way which reduce the need to travel by personalized modes and increase of public transport system;

- Improvement of public transport system and its efficiency;

- Optimization of existing transport infrastructure and give precedence to low cost and affordable technology, at least as a short-term measure, especially bus technology;

- Promote the health of the people by encouraging more walking and cycling; and

- Ensure that the development of the transport system contributes to the protection and enhancement of the natural and built environment.

\section{References}

Accidental Deaths \& Suicides in India, (Various Issues), National Crime Records Bureau, Ministry of Home Affairs, Government of India, New Delhi.

Affuso, L., Masson, J. and Newbery, D. (2000) Comparing Investments on New Transport Infrastructure: Roads vs Railways?, Development of Applied Economics, University of Cambridge.

Agarwal, O. P. (2001) "Towards a National Urban Transport Policy", Indian Journal of Transport Management, Vol. 25, Issue 6, pp. 593-616.

Amsler, Y. (1996) "Great Metropolis Development and Transportation Policy", Urban Transport in Developing Countries, CODATU VII, New Delhi, TOME 1, February 1996, pp. 1-11.

Census of India (1991) Registrar General \& Census Commissioner, Ministry of Home Affairs, Government of India, New Delhi.

Centre for Science and Environment, (1996), Slow Murder, CSE, New Delhi, India.

De Rus, G. and Nombela, G. (1997) "Privatisation of Urban Bus Services in Spain", Journal of Transport Economics and Policy, Vol. 31, Issue 1, pp. 115-129.

Draft Regional Plan for Bombay Metropolitan Region 1996-2011, (1995), Bombay Metropolitan Regional Development Authority.

Economic Survey of Delhi 1999-00, (2000) Planning Department, Government of NCT of Delhi, India.

Ghee, C. et al. (1997) "Socio Economic Aspects of Road Accidents in Developing Countries", TRL Report, TRL 247, Transport Research Laboratory, Crowthorne.

Gopalaswami, T. V. (1996) "Policy for Efficient Public Transport in a Competitive Setting", Indian Journal of Transport Management, Vol. 20, Issue 3, pp. 169-178.

Greater London Authority (2001) The Mayor's Transport Strategy, Draft for Public Consultation.

Ingram, Gregory K. (1998) "Patterns of Metropolitan Development: What Have We Learned?", Urban Studies, Vol. 35, Issue 7, pp. 1019-1035.

Jansson, K. and Wallin, B. (1991) "Developments in Transport Policy: Deregulation of Public Transport in Sweden", Journal of Transport Economics and Policy, Vol. 25, Issue 1, pp. 97-107.

McMullen, B. S. and Stanley, L. R. (1988) "The Impact of Deregulation on the Production Structure of the Motor Carrier Industry", Economic Inquiry, Vol. 26, Issue 2, pp. 299-316.

Meyer, John R. and Gomez-Ibanez, J. A. (1981) Autos, Transit, and Cities, Cambridge, Harvard University Press. 
Mills, Edwin S., and Becker, C. M. (1986) Studies in Indian Urban Development, New York, Oxford University Press.

Mohan, D. (2002) "Work Trips and Safety of Bicyclists", Indian Journal of Transport Management, Vol. 26, Issue 2, pp. 225-233.

Mohan, N. C. (2001) "The Paradox of Urbanisation", The Financial Express, July $26^{\text {th }}$.

Motor Transport Statistics of India, (Various Issues), Transport Research Wing, Ministry of Road Transport \& Highways, Government of India, New Delhi.

Munnell, Alicia H. (1992) "Infrastructure Investment and Economic Growth", Journal of Economic Perspectives, Vol. 6, No. 4, pp. 189-198.

Newman, P. W .G. and Kenworthy, J. R. (1991) Cities and Automobile Dependence: An International Sourcebook, Aldershot, U. K., Avebury Technical Publishing.

Padam, S. (2001) “Transport and Urban Governance”, Urban Transport Journal, Vol. 2, No. 1, pp. 30-33.

Parry, R. (2000) "Marketing - A Transport Strategy", Public Transport International, Vol. 49, Issue, 2, pp. 6-9.

Ramachandran, R. (1989) Urbanization and Urban Systems in India, Oxford University Press, Oxford, England.

Ramanathan, R. and Parikh, J. (1999) "Transport Sector in India: The Analysis in the Context of Sustainable Development", Transport Policy, Vol. 6, Issue 1, pp. 35-45.

Ramanathan, R. (1998) "Development of Indian Passenger Transport", Energy - The International Journal, Vol. 23, Issue 5, pp. 429-430.

Ranganathan, N. (1995) "National Urban Transport Policy - A Framework", Indian Journal of Transport Management, Vol. 19, No. 2, pp. 85-98.

Report of the Working Group on Urban Transport, (1996), Ministry of Urban Affairs and Employment, Government of India, New Delhi.

Sengupta, R. (2001) Sustainable Transport Pricing in India, Asian Institute of Transport Development, New Delhi.

Sharma, N. P. and Mishra, S. (1998) “Transport for Healthy Tomorrow, Issues and Options”, Presented during the Seminar on Planning Delhi: Healthy City in the next Millennium, DRC, ITPI, New Delhi, 1998.

Sibal, V. and Sachdeva, Y. (2001) "Urban Transport Scenario in India and Its Linkages with Energy and Environment”, Urban Transport Journal, Vol. 2, No. 1, pp. 34-55.

Sikdar, P. K. (1995) "Justification of Subsidy in Urban Bus Systems", Indian Journal of Transport Management, Vol. 19, Issue 2, pp. 135-146.

Singal, B. I. (2000) "Urban Transport Strategy for Indian Cities”, Urban Transport Journal, Vol. 1, No. 1, pp. 24-34.

Singh, S. K. (2005) "Review of Urban Transportation in India", Journal of Public Transportation, Vol. 8, Issue 1, pp. 79-97.

Singh, S. K. (2002) "An Analysis of Economic Profitability of Municipal Transport Undertakings in India”, Indian Journal of Transport Management, Vol. 26, Issue 4, pp. 535-557.

Singh, S. K. (2001) "The Public and Private Sector Role in the Provision of Infrastructure Services", Indian Journal of Transport Management, Vol. 25, Issue 3, pp. 191-197.

Singh, S. K. (2000) "Estimating the Level of Rail- and Road-based Passenger Mobility in India", Indian Journal of Transport Management, Vol. 24, Issue 12, pp. 771-781.

Singh, S. K. and Misra, A. (2001) "Road Accident Analysis: A Case Study of Patna City", Urban Transport Journal, Vol. 2, Issue 2, pp. 60-75.

Small, K. and Shunfeng, Song (1992) "Wasteful Commuting: A Resolution", Journal of Political Economy, Vol. 100, Issue 4, pp. 888-898.

Sriraman, S. (1998) "Road Transport Development in India”, Current Science, Vol. 75, Issue 8, pp. 78590.

State Transport Undertakings - Profile and Performance, (Various Issues), Central Institute of Road Transport, Pune, India.

Traffic and Transportation Policies and Strategies in Urban Areas in India, (1998) Final Report, Ministry of Urban Development, Government of India, New Delhi.

Umrigar, F. S.,and Sikdar, P. K. (1996) "Urban Mobility through Competitive Advantage of Bus System”, Indian Journal of Transport Management, Vol. 20, Issue 3, pp. 199-208.

Urban Statistics, (1996) Central Pollution Control Board, New Delhi, India.

Viton, P.A. (1986) “The Question of Efficiency in Urban Bus Transportation”, Journal of Regional Science, Vol. 26, Issue 3, pp. 499-513. 
European Transport $\backslash$ Trasporti Europei n. 27 (2004): 26-44

World Bank (1996) Sustainable Transport: Priorities for Policy Reform, Washington, D.C.

World Bank (1994) "World Development Report 1994: Infrastructure for Development", Oxford University Press, New York.

World Bank (1991) "Urban Policy and Economic Development: An Agenda for the 1990s", Washington, D.C.

World Bank (1986) “Urban Transport, a World Bank Policy Study”, World Bank, Washington, D.C. 